\title{
Transcatheter aortic valve implantation in the Asia-Pacific region: is it ready for prime time?
}

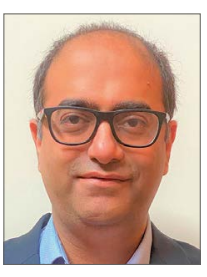

Tarun Chakravarty*, MD; Raj Makkar, MD

Smidt Heart Institute at Cedars-Sinai Medical Center, Los Angeles, CA, USA

The research and development, clinical trials, and commercialisation of transcatheter aortic valve implantation (TAVI) technology were initially limited to the western world, including Canada, Europe and North America. Multiple randomised clinical trials over the last decade have now established TAVI as the standard of care for the treatment of severe symptomatic aortic stenosis, especially of the trileaflet aortic valve, irrespective of surgical risk ${ }^{1-10}$. With the cumulative evidence establishing TAVI as a recognised option for the treatment of aortic stenosis, increasing numbers of patients are being treated in the Asia-Pacific region with TAVI technology. There are no randomised clinical trials, and limited registry data ${ }^{11,12}$, on the performance of TAVI for the treatment of aortic stenosis in the Asia-Pacific region.

This paucity of data on the outcomes of TAVI in the AsiaPacific region underpins the study by Tay and colleagues in this issue of AsiaIntervention ${ }^{13}$.

Article, see page 54

The authors report the clinical outcomes in 1,125 consecutive patients who underwent TAVI between 2009 and 2017 with commercially available transcatheter heart valves in seven medical centres in the Asia-Pacific region. This was a prospective, multicentre registry and clinical data were collected on uniform case report forms. The study endpoints were defined according to the standard updated Valve Academic Research Consortium (VARC-2) and American Society of Echocardiography (ASE) guidelines. Bicuspid aortic valve was present in $6 \%$ of the patients and a Society of Thoracic Surgeons (STS) score of less than $4 \%$ was noted in $26.4 \%$ of the patients. The authors report the following principal findings. (1) The 30-day mortality after TAVI was $2.5 \%$. (2) The incidence of acute procedural complications was relatively low, with acute kidney injury noted in $6.8 \%$, major vascular complications in $5.8 \%$, stroke in $1.2 \%$ and major bleeding in $1.2 \%$ of the patients. (3) History of stroke prior to the procedure or occurrence of a stroke after the TAVI procedure was independently associated with increased risk of 30-day mortality after TAVI.

It is remarkable that, despite the use of early-generation valves in most patients in this study, the overall 30-day mortality was $2.5 \%$. Even in the patients receiving early-generation transcatheter heart valves, the 30 -day mortality was only $3.5 \%$, while the 30 -day mortality was $1.1 \%$ in patients receiving contemporary 
transcatheter heart valves. Contemporary transcatheter heart valves were used in less than $25 \%$ of the patients (Evolut ${ }^{\mathrm{TM}} \mathrm{R}$ [Medtronic, Minneapolis, MN, USA] in $13.2 \%$ and SAPIEN 3 [Edwards Lifesciences, Irvine, CA, USA] in $8 \%$ of the patients). Seventy percent of the TAVI procedures were performed with early-generation transcatheter heart valves (CoreValve ${ }^{\circledR}$ [Medtronic] in $19.5 \%$, SAPIEN XT in $25.8 \%$ and SAPIEN in 5.1\% [both Edwards Lifesciences]). The incidence of moderate paravalvular regurgitation was high in this study, present in $17 \%$ of the patients, probably due to the use of early-generation transcatheter heart valves. An important limitation of this study is the lack of some data, with information on valve type missing in $22 \%$ of the patients, valve size missing in $5.8 \%$, and information on vascular access missing in $11.2 \%$.

The transfemoral approach was the predominant approach (91.1\%), with the transapical approach being the second most frequently used access. The use of the transapical or transaortic approach for TAVI is expected to fall out of favour, as the incidence of death or stroke was significantly higher at five years in patients undergoing TAVI by the transapical or transaortic approach compared with open heart surgery in the PARTNER intermediate-risk study ${ }^{10}$. Perhaps subclavian, transcarotid or transcaval vascular access may be the preferred approach in patients undergoing TAVI by an alternative access.

This is the first report of the Asia Pacific Society of Interventional Cardiology (APSIC)-sponsored TAVI registry. Similar prospective registries in other countries have led the way in reporting the national outcomes of TAVI following the commercialisation of TAVI technology, for instance, the Society of Thoracic Surgeons/ American College of Cardiology Transcatheter Valve Therapies (STS/ACC TVT) registry ${ }^{14,15}$ and FRANCE 2 registry ${ }^{16}$. These national registries have played a critical role in the rational spread of TAVI technology and optimisation of clinical outcomes. These registries provide a platform to assess the outcomes of TAVI overall as well as for individual TAVI programmes, improve understanding of the procedure, identify patients who would benefit or not benefit from this procedure, enable creation of risk models unique to each patient population, and provide valuable information about the type and size of the devices used in the patient population in different geographic regions and the unique challenges faced by different healthcare systems. The authors have taken the lead in the Asia-Pacific region towards establishing such prospective registries to monitor clinical outcomes. While the data presented in this study are not representative of national databases, the reporting centres are centres of excellence in the Asia-Pacific region and provide a benchmark for procedural and clinical outcomes as TAVI technology spreads across the developing world.

\section{Conflict of interest statement}

T. Chakravarty is a consultant for Edwards Lifesciences, Medtronic, Abbott and Boston Scientific. R. Makkar is a consultant to and receives research grants from Edwards Lifesciences, Medtronic, Abbott and Boston Scientific.

\section{References}

1. Leon MB, Smith CR, Mack M, Miller DC, Moses JW, Svensson LG, Tuzcu EM, Webb JG, Fontana GP, Makkar RR, Brown DL, Block PC, Guyton RA, Pichard AD, Bavaria JE, Herrmann HC, Douglas PS, Petersen JL, Akin JJ, Anderson WN, Wang D, Pocock S; PARTNER Trial Investigators. Transcatheter aortic-valve implantation for aortic stenosis in patients who cannot undergo surgery. N Engl J Med. 2010;363:1597-607.

2. Smith CR, Leon MB, Mack MJ, Miller DC, Moses JW, Svensson LG, Tuzcu EM, Webb JG, Fontana GP, Makkar RR, Williams M, Dewey T, Kapadia S, Babaliaros V, Thourani VH, Corso P, Pichard AD, Bavaria JE, Herrmann HC, Akin JJ, Anderson WN, Wang D, Pocock SJ; PARTNER Trial Investigators. Transcatheter versus surgical aortic-valve replacement in high-risk patients. N Engl J Med. 2011;364:2187-98.

3. Adams DH, Popma JJ, Reardon MJ, Yakubov SJ, Coselli JS, Deeb GM, Gleason TG, Buchbinder M, Hermiller J Jr, Kleiman NS, Chetcuti S, Heiser J, Merhi W, Zorn G, Tadros P, Robinson N, Petrossian G, Hughes GC, Harrison JK, Conte J, Maini B, Mumtaz M, Chenoweth S, Oh JK; U.S. CoreValve Clinical Investigators. Transcatheter aortic-valve replacement with a selfexpanding prosthesis. N Engl J Med. 2014;370:1790-8.

4. Kapadia SR, Leon MB, Makkar RR, Tuzcu EM, Svensson LG, Kodali S, Webb JG, Mack MJ, Douglas PS, Thourani VH, Babaliaros VC, Herrmann HC, Szeto WY, Pichard AD, Williams MR, Fontana GP, Miller DC, Anderson WN, Akin JJ, Davidson MJ, Smith CR; PARTNER trial investigators. 5-year outcomes of transcatheter aortic valve replacement compared with standard treatment for patients with inoperable aortic stenosis (PARTNER 1): a randomised controlled trial. Lancet. 2015;385:2485-91.

5. Mack MJ, Leon MB, Smith CR, Miller DC, Moses JW, Tuzcu EM, Webb JG, Douglas PS, Anderson WN, Blackstone EH, Kodali SK, Makkar RR, Fontana GP, Kapadia S, Bavaria J, Hahn RT, Thourani VH, Babaliaros V, Pichard A, Herrmann HC, Brown DL, Williams M, Akin J, Davidson MJ, Svensson LG; PARTNER 1 trial investigators. 5-year outcomes of transcatheter aortic valve replacement or surgical aortic valve replacement for high surgical risk patients with aortic stenosis (PARTNER 1): a randomised controlled trial. Lancet. 2015;385:2477-84.

6. Leon MB, Smith CR, Mack MJ, Makkar RR, Svensson LG, Kodali SK, Thourani VH, Tuzcu EM, Miller DC, Herrmann HC, Doshi D, Cohen DJ, Pichard AD, Kapadia S, Dewey T, Babaliaros V, Szeto WY, Williams MR, Kereiakes D, Zajarias A, Greason KL, Whisenant BK, Hodson RW, Moses JW, Trento A, Brown DL, Fearon WF, Pibarot P, Hahn RT, Jaber WA, Anderson WN, Alu MC, Webb JG; PARTNER 2 Investigators. Transcatheter or Surgical Aortic-Valve Replacement in Intermediate-Risk Patients. $N$ Engl J Med. 2016;374:1609-20.

7. Reardon MJ, Van Mieghem NM, Popma JJ, Kleiman NS, Søndergaard L, Mumtaz M, Adams DH, Deeb GM, Maini B, Gada H, Chetcuti S, Gleason T, Heiser J, Lange R, Merhi W, Oh JK, Olsen PS, Piazza N, Williams M, Windecker S, Yakubov SJ, Grube E, Makkar R, Lee JS, Conte J, Vang E, Nguyen H, Chang Y, 
Mugglin AS, Serruys PW, Kappetein AP; SURTAVI Investigators. Surgical or Transcatheter Aortic-Valve Replacement in Intermediate-Risk Patients. N Engl J Med. 2017;376:1321-31.

8. Mack MJ, Leon MB, Thourani VH, Makkar R, Kodali SK, Russo M, Kapadia SR, Malaisrie SC, Cohen DJ, Pibarot P, Leipsic J, Hahn RT, Blanke P, Williams MR, McCabe JM, Brown DL, Babaliaros V, Goldman S, Szeto WY, Genereux P, Pershad A, Pocock SJ, Alu MC, Webb JG, Smith CR; PARTNER 3 Investigators. Transcatheter Aortic-Valve Replacement with a Balloon-Expandable Valve in Low-Risk Patients. N Engl J Med. 2019;380:1695-705. 9. Popma JJ, Deeb GM, Yakubov SJ, Mumtaz M, Gada H, O’Hair D, Bajwa T, Heiser JC, Merhi W, Kleiman NS, Askew J, Sorajja P, Rovin J, Chetcuti SJ, Adams DH, Teirstein PS, Zorn GL 3rd, Forrest JK, Tchétché D, Resar J, Walton A, Piazza N, Ramlawi B, Robinson N, Petrossian G, Gleason TG, Oh JK, Boulware MJ, Qiao H, Mugglin AS, Reardon MJ; Evolut Low Risk Trial Investigators. Transcatheter Aortic-Valve Replacement with a Self-Expanding Valve in Low-Risk Patients. N Engl J Med. 2019;380:1706-15. 10. Makkar RR, Thourani VH, Mack MJ, Kodali SK, Kapadia S, Webb JG, Yoon SH, Trento A, Svensson LG, Herrmann HC, Szeto WY, Miller DC, Satler L, Cohen DJ, Dewey TM, Babaliaros V, Williams MR, Kereiakes DJ, Zajarias A, Greason KL, Whisenant BK, Hodson RW, Brown DL, Fearon WF, Russo MJ, Pibarot P, Hahn RT, Jaber WA, Rogers E, Xu K, Wheeler J, Alu MC, Smith CR, Leon MB; PARTNER 2 Investigators. Five-Year Outcomes of Transcatheter or Surgical Aortic-Valve Replacement. N Engl J Med. 2020;382:799-809.

11. Ishizu K, Shirai S, Isotani A, Hayashi M, Kawaguchi T, Taniguchi T, Ando K, Yashima F, Tada N, Yamawaki M, Naganuma T, Yamanaka F, Ueno H, Tabata M, Mizutani K, Takagi K, Watanabe Y, Yamamoto M, Hayashida K; OCEAN-TAVI Investigators. Long-Term Prognostic Value of the Society of Thoracic Surgery Risk Score in Patients Undergoing Transcatheter Aortic Valve Implantation (From the OCEAN-TAVI Registry). Am J Cardiol. 2021;149:86-94.

12. Takeji Y, Taniguchi T, Morimoto T, Saito N, Ando K, Shirai S, Sakaguchi G, Arai Y, Fuku Y, Kawase Y, Komiya T, Ehara N, Kitai T, Koyama T, Watanabe S, Watanabe H, Shiomi H,
Minamino-Muta E, Matsuda S, Yaku H, Yoshikawa Y, Yamazaki K, Kawatou M, Sakamoto K, Tamura T, Miyake M, Sakaguchi H, Murata K, Nakai M, Kanamori N, Izumi C, Mitsuoka H, Kato M, Hirano Y, Inada T, Nagao K, Mabuchi H, Takeuchi Y, Yamane K, Tamura T, Toyofuku M, Ishii M, Inoko M, Ikeda T, Ishii K, Hotta K, Jinnai T, Higashitani N, Kato Y, Inuzuka Y, Morikami Y, Minatoya K, Kimura T; the CURRENT AS Registry Investigators and K-TAVI Registry Investigators. Transcatheter Aortic Valve Implantation vs. Surgical Aortic Valve Replacement for Severe Aortic Stenosis in Real-World Clinical Practice. Circ J. 2020; 84:806-14

13. Tay E, Khaing T, Yin WH, Posas EF, Kao PH, Buddhari W, Hayashida K, Ho KW, Lin MS, Yap J, Zhang JJ, Chiam PTL, Rosli MA, Park SJ, Udayacherm W, Yanagisawa R, Tan HC, Lee MK. Asia Pacific TAVI registry (an APSIC initiative): initial report of early outcomes. AsiaIntervention. 2021;7:54-9.

14. Vemulapalli S, Carroll JD, Mack MJ, Li Z, Dai D, Kosinski AS, Kumbhani DJ, Ruiz CE, Thourani VH, Hanzel G, Gleason TG, Herrmann HC, Brindis RG, Bavaria JE. Procedural Volume and Outcomes for Transcatheter Aortic-Valve Replacement. $N$ Engl J Med. 2019;380:2541-50

15. Makkar RR, Yoon SH, Leon MB, Chakravarty T, Rinaldi M, Shah PB, Skipper ER, Thourani VH, Babaliaros V, Cheng W, Trento A, Vemulapalli S, Kapadia SR, Kodali S, Mack MJ, Tang GHL, Kaneko T. Association Between Transcatheter Aortic Valve Replacement for Bicuspid vs Tricuspid Aortic Stenosis and Mortality or Stroke. JAMA. 2019;321:2193-202.

16. Gilard M, Eltchaninoff $\mathrm{H}$, Iung B, Donzeau-Gouge $\mathrm{P}$, Chevreul K, Fajadet J, Leprince P, Leguerrier A, Lievre M, Prat A, Teiger E, Lefevre T, Himbert D, Tchetche D, Carrié D, Albat B, Cribier A, Rioufol G, Sudre A, Blanchard D, Collet F, Dos Santos P, Meneveau N, Tirouvanziam A, Caussin C, Guyon P, Boschat J, Le Breton H, Collart F, Houel R, Delpine S, Souteyrand G, Favereau X, Ohlmann P, Doisy V, Grollier G, Gommeaux A, Claudel JP, Bourlon F, Bertrand B, Van Belle E, Laskar M; FRANCE 2 Investigators. Registry of transcatheter aortic-valve implantation in high-risk patients. $N$ Engl $\mathrm{J} \mathrm{Med}$. 2012;366:1705-15. 